\title{
MONUMENT STATUE STUDY OF NANI WARTABONE STRUGGLE THROUGH BACKGROUND AND ITS VISUALIZATION
}

\author{
Muhammad Isla \\ Postgraduate Program Master of Design Study Program \\ Indonesian Computer University \\ Jl. Dago (Ir. H. Djuanda) 160-162, Bandung, 40132 \\ e-mail: muhammadisla07@gmail.com

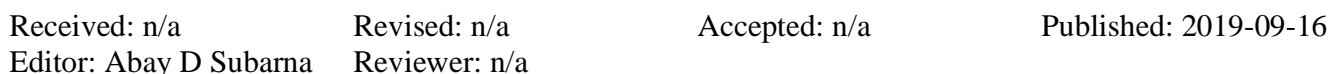

\begin{abstract}
This study aims to find out how to study the Nani Wartabone statue in terms of visuals, to provide knowledge to the people of Gorontalo the meaning of the Nani Wartabone statue and to describe the background study and visualization of the Tilongolo Nani Wartabone monument statue. This research was written using descriptive qualitative research methods, the authors observed in detail the background and visualization of the Tilongolo Nani Wartabone monument, the results of this study allow the writer to know the historical background of the Tilongolo Nani Wartabone monument statue and the writer can also know the visual meaning of the Tilongolo Monument statue Nani Wartabone. The research results obtained by the author are quite good because there are two sources who are quite helpful in the process of writing this research, the conclusion or the final result of this study is that the writer and the public can find out the background of the Nani Wartabone statue made to commemorate his services in fighting the invaders and the meaning of the visualization of the statue of the struggle of Nani Wartabone, namely: (1) The pointing hand has a meaning, namely his birthplace, Bube Village, Suwawa District, Bone Bolango Regency, Gorontalo Province; (2) Bayonet in the left pocket is made by Suwawa which has the mystical power to protect Nani Wartabone in certain situations; (3) The pistol in the right pocket is used as a helper for the main weapon in the left hand of Nani Wartabone; (4) The weapon in the left hand of Nani Wartabone is a long rifle (hunting rifle) that can be used on the battlefield; (5) The Safari uniform used by Nani Wartabone has patriotic meaning and strength; and (6) Base of 2 and the curve of base of 3 represents the number 23 celebrated as patriotic day by the people of Gorontalo.
\end{abstract}

Keywords: Statue of Struggle Statue of Nani Wartabone, Background, visualization, Gorontalo City

\begin{abstract}
Abstrak. Penelitian ini bertujuan untuk mengetahui bagaimana mempelajari patung Nani Wartabone dalam hal visual, untuk memberikan pengetahuan kepada masyarakat Gorontalo tentang makna patung Nani Wartabone dan untuk menggambarkan studi latar belakang dan visualisasi patung monumen Tilongolo Nani Wartabone. Penelitian ini ditulis dengan menggunakan metode penelitian deskriptif kualitatif, penulis mengamati secara detail latar belakang dan visualisasi dari monumen Tilongolo Nani Wartabone, hasil penelitian ini memungkinkan penulis untuk mengetahui latar belakang sejarah dari patung monumen Tilongolo Nani Wartabone dan penulis dapat juga tahu makna visual dari patung Monumen Tilongolo Nani Wartabone. Hasil penelitian yang diperoleh oleh penulis cukup baik karena ada dua sumber yang cukup membantu dalam proses penulisan penelitian ini, kesimpulan atau hasil akhir dari penelitian ini adalah bahwa penulis dan masyarakat dapat mengetahui latar belakang dari Patung
\end{abstract}

Publisher: Universitas Komputer Indonesia

Copyright: The Author(s) 2018 DOI: 10.34010/artic.2019.4.2456.193-202 
Nani Wartabone dibuat untuk mengenang jasa-jasanya dalam memerangi penjajah dan makna visualisasi patung perjuangan Nani Wartabone, yaitu: (1) Tangan menunjuk memiliki makna, yaitu tempat kelahirannya, Desa Bube, Distrik Suwawa, Kabupaten Bone Bolango, Provinsi Gorontalo; (2) Bayonet di saku kiri dibuat oleh Suwawa yang memiliki kekuatan mistis untuk melindungi Nani Wartabone dalam situasi tertentu; (3) Pistol di saku kanan digunakan sebagai penolong untuk senjata utama di tangan kiri Nani Wartabone; (4) Senjata di tangan kiri Nani Wartabone adalah senapan panjang (senapan berburu) yang dapat digunakan di medan perang; (5) Seragam Safari yang digunakan oleh Nani Wartabone memiliki makna dan kekuatan patriotik; (6) Basis 2 dan kurva 3 mewakili angka 23 diperingati sebagai hari patriotik oleh masyarakat Gorontalo

Kata kunci: Kota Gorontalo; Latar Belakang; Monumen Perjuangan Nani Wartabone, , Visual.

\section{INTRODUCTION}

[1] Most provincial capitals in Indonesia have objects that serve as icons or symbols that serve as markers that remind people of an area of a city, province, country and so on. [2] Not only the provincial capitals in Indonesia have icons, but foreign countries also have objects or symbols that are used as markers of the country, for example the country of France which is famous for the Eiffel tower which is used as an icon of that country. [3] One of the regions in Indonesia, precisely on the island of Sulawesi, in Gorontalo Province also has an object that is used as an icon of the city. To commemorate the services of the national hero Mr. Hj. Nani Wartabone, the Gorontalo community took the initiative to build a statue that would later become an icon of the city of Gorontalo and to commemorate the patriotic event in Gorontalo. The event was the independence day of the Indonesian people who were in Gorontalo from the invaders at the time.

The author or researcher limits the scope of the study due to the breadth of the scope of the research problem regarding sculpture, the researcher limits the research as follows:

1. From the aspect of research, limited only to the visualization of Nani Wartabone statue.

2. From the research subjects, limited to only statue of Nani Wartabone in the Province of Gorontalo.

3. The study was conducted on a visual appearance of the statue of Nani Wartabone

\section{METHOD}

A data is a source of information obtained from the results of research. Data that has been processed will be information that will be utilized by the reader. In this study, it will be obtained with two events, namely primary data and secondary data. And as for the translation of the two data sources are as follows:

\section{Primary Data}

Primary data is data obtained directly from the speakers. The data can be obtained through interviews with informants. In determining the resource persons, the sample aims to obtain accurate data. In this study the informants taken are the head of the Culture and tourism office itself and the people associated with the development of the Nani Wartabone link, the purpose of which is to find out information about what factors are related to the Nani Wartabone statue that will be studied.

\section{Secondary Data}

Secondary data is one of the data obtained by researchers to support primary data, such as the use of literature and literature such as books about sculpture, visual studies and meaning to be examined. The data is data taken related to the focus of the research object. In carrying out this research, it requires a technique in data collection in which the data collection is carried out 
sequentially both in qualitative data collection and quantitative data will be mutually support one another.

\section{RESULTS AND DISCUSSION}

3.1 Description of the Nani Wartabone Statue

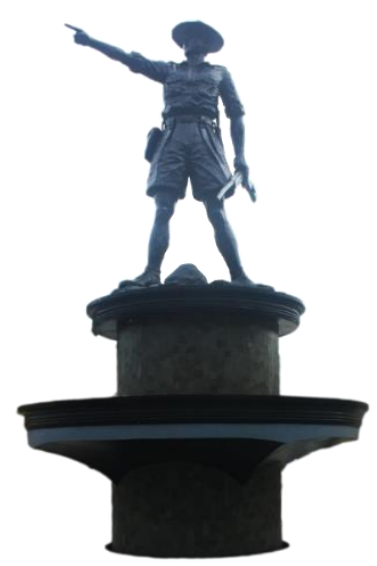

Figure 1 Statue of Nani Wartabone

(Photo Source: Author, 2018)

The Nani Wartabone statue was built on the idea of Mr. Yosh Nani Wartabone who was the second son of Nani Wartabone himself, and after going through several deliberations processes the construction of the statue was built in 1988 by an architect named Kristanto from Jakarta. The Nani Wartabone statue is made using bronze and has a color like bronze, where the Nani wartabone statue stands (base) has a rocky surface and there are several stones around the foot of the Nani Wartabone statue. After the construction of the statue was completed, the Mayor of Gorontalo at the time Drs. Ahmad Nadjamuddin inaugurated the statue of Nani Wartabone as an icon of the city of Gorontalo and is a historical story of the Gorontalo people in fighting the invaders under the leadership of Mr. H. Nani Wartabone (Figure 1).

\subsection{The size of the Nani Wartabone statue}

Based on observations made by the author, the size of the statue of Nani Wartabone is as shown in the picture below (Figure 2) 


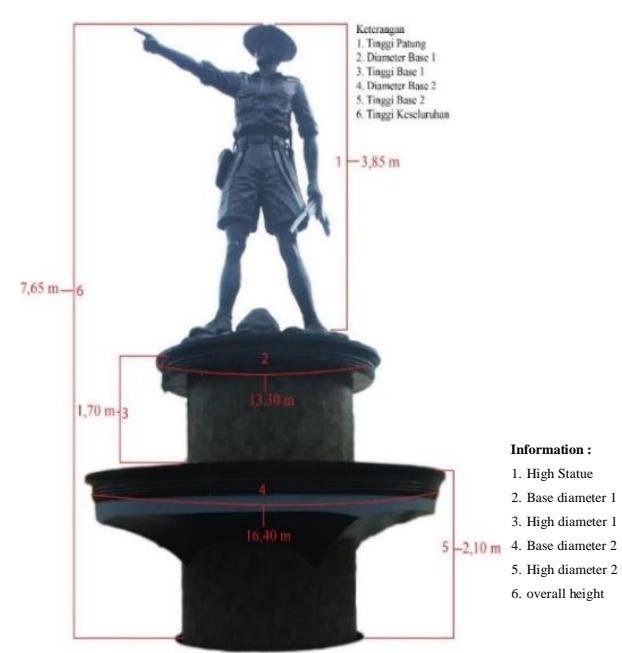

Figure 2 Size of the Nani Wartabone Statue (Photo Source: Author, 2018)

\subsection{Visual significance of the statue of Nani Wartabone}

Based on the results of interviews with Mr. Writer with Mr. Yosh Nani Wartabone (Son of Nani Wartabone), the meaning of the statue of Nani Wartabone is as shown in Figure 3.

\subsection{Nani Wartabone Statue Gesture}

From the author's observations of the object examined (the statue of Nani Wartabone) in Figure 1 , we get the attitude or gesture of the statue of Nani Wartabone as shown in Table 1.

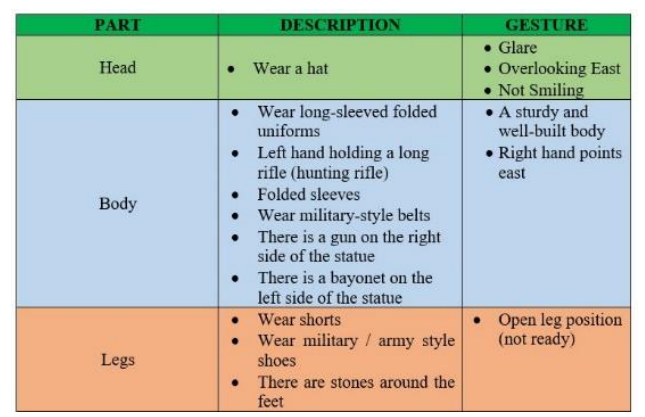

Table 1 Description and Attitudes (Gesture) of Nani Wartabone Monument Statue 


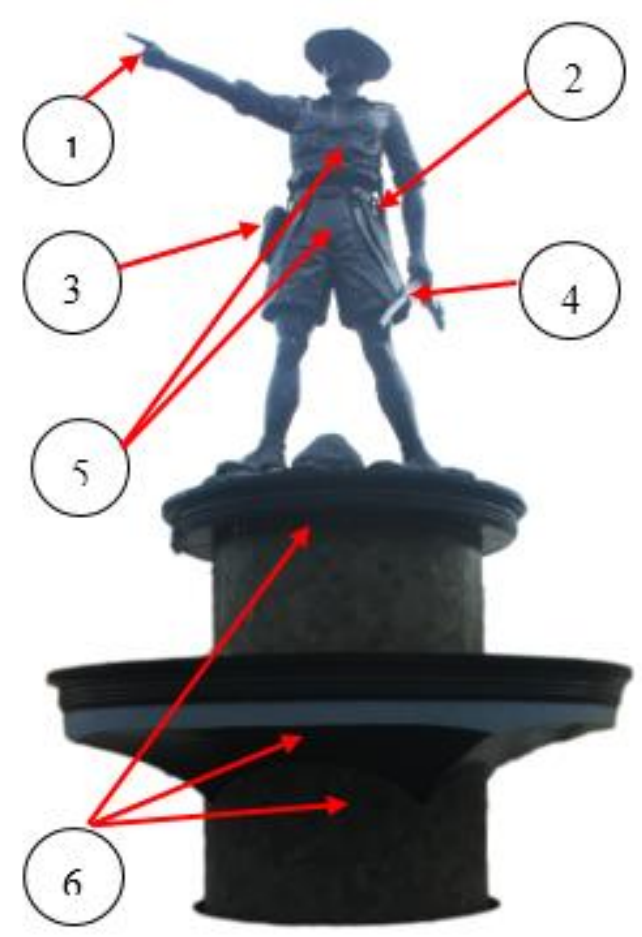

1. The pointing hand has a meaning, namely his birthplace, Bube Village, Suwawa District, Bone Bolango Regency, Gorontalo Province

2. Bayonet in the left pocket is made by Suwawa which has the mystical power to protect Nani Wartabone in certain situations.

3. The pistol in the right pocket is used as a helper for the main weapon in the left hand of Nani Wartabone.

4. The weapon in the left hand of Nani Wartabone is a long rifle (hunting rifle) that can be used on the battlefield.

5. The Safari uniform used by Nani Wartabone has patriotic meaning and strength.

6. Base of 2 and the curve of base of 3 represents the number 23 celebrated as patriotic day by the people of Gorontalo.

Source : Dr. Yosh Nani Wartabone, 2018

Figure 3. Meaning of Nani Wartabone Struggle Monument Statue

\subsection{Description of the Monument of Struggle Nani Wartabone}

The Nani Wartabone struggle monument which is now known as the Tilongolo monument Nani Wartabone was built in conjunction with the Nani Wartabone statue. The monument was built on the basis of Nani Wartabone's dedication and struggle for the Gorontalo area, so the community took the initiative to build a menumen to commemorate Nani Wartabone's services. The monument was inaugurated directly by Mr. C.J Rantung (Governor of North Sulawesi) on August 17, 1987.

After undergoing several renovations, now inside this monument there are objects other than the statue of Nani Wartabone, including four reliefs and two tanks (additional objects), inside this monument there are also writing teenage cadets written in large sizes to beautify the visual appearance of this monument.

The following is a brief description of the objects contained in the Nani Wartabone struggle monument as follows:

\section{Statue}

The statue contained in this monument is the statue of Nani Wartabone, this statue is the main object of this monument, because this statue is the main symbol of Indonesian independence in Gorontalo.

\section{Relief}

Relief pada monumen tilongolo nani wartabone dibangun untuk memperlihatkan perjuangan rakyat Gorontalo dalam melawan penjajah dalam bentuk visual atau gambar. Relief ini dibangun pada tahun 2018 dan ditempatkan di bagian monumen tilongolo nani watabone. Terdapat empat buah relief yang terdapat pada monumen Nani Wartabone yang terbuat dari beton, keempat relief tersebut berdiri dibelakang patung Nani Wartabone dan menempel pada suatu objek semacam dinding yang dibuat untuk menempelkan relief-relief ini, dua buah relief terdapat pada sisi kanan belakang patung Nani Wartabone dan dua buah relief lainnya terdapat pada sisi kiri belakang patung Nani Wartabone. 
In Figure 4, there are two reliefs located on the back right side of the Nani Wartabone statue which has a story about the condition of the Gorontalo community, the majority of which residents work as farmers and fishermen. In addition, this relief also tells the arrival of the Dutch army in Gorontalo and there is an attitude of rejection from the community shown by the gesture of one of the foremost seen in the relief. In addition, the relief shows the people's struggle to fight against the invaders who came to Gorontalo.

In Figure 5 there are two reliefs located on the left rear side of the Nani Wartabone statue. This relief tells the expression of the excitement of the Gorontalo people who were free from Dutch colonialism at that time. And this relief also has the story of the raising of the Red and White flag for the first time in Gorontalo after the Gorontalo people succeeded in driving out the invaders who came precisely at the youth cadet field or the location of the Nani Wartabone warrior monument at this time.
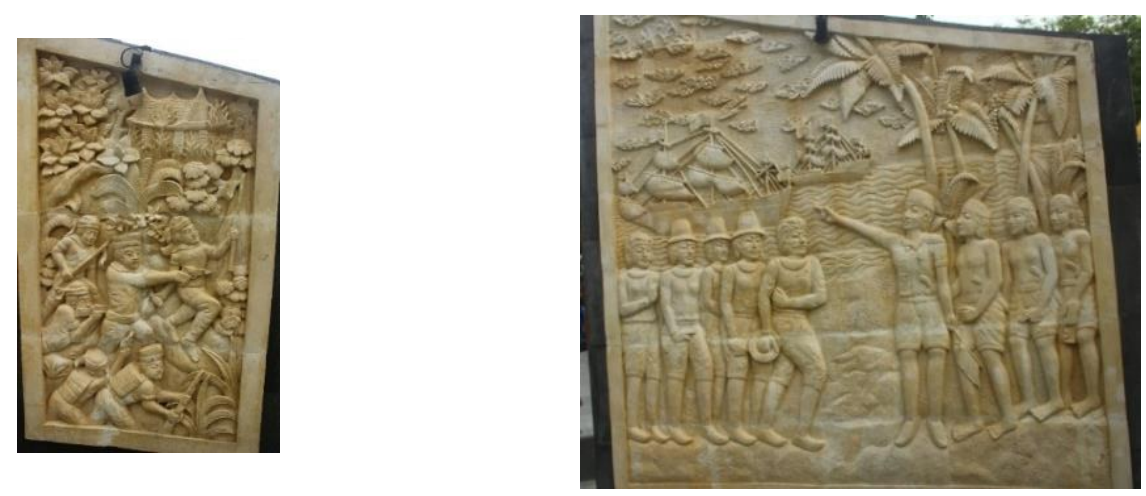

Figure 4 Relief Right side of Nani Wartabone statue

(Photo source: Author, 2018)
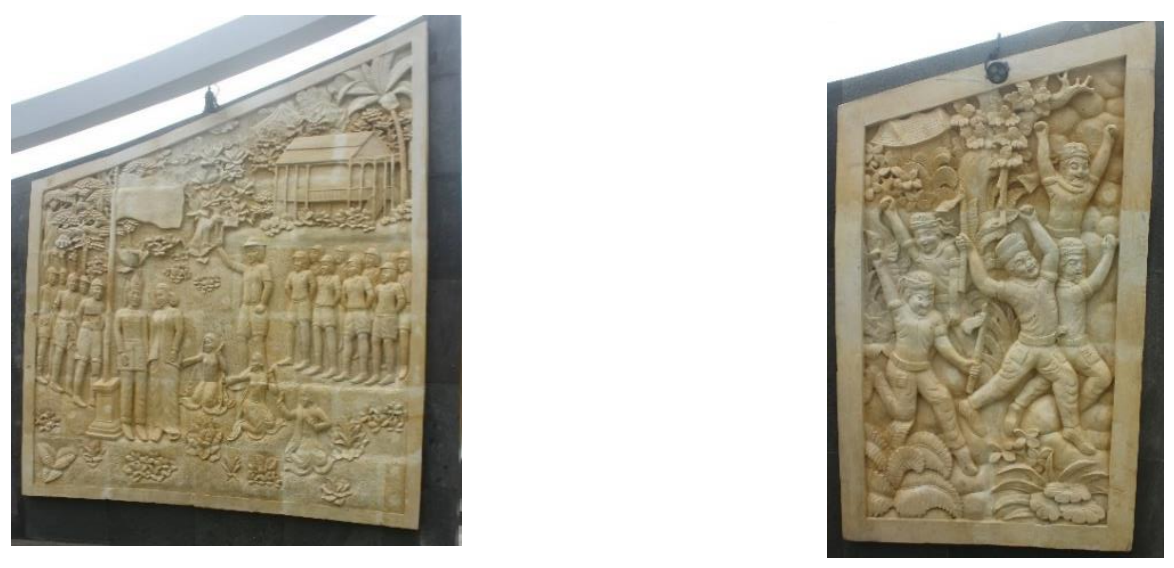

Figure 5 Relief Left side of Nani Wartabone statue

(Photo source: Author, 2018) 


\section{Battle Cars (Tank)}

The war car (tank) on display in this monument has no connection or historical value with the statue of Nani Wartabone or the struggle of the people of Gorontalo, this tank is displayed only to further enhance the appearance of this monument and to attract tourists to come to Gorontalo and visit the Tilongolo monument Nani Wartabone. There are two tanks on the Nani Wartabone monument, one occupies the right front side of the Nani Wartabone statue and the other one is on the front left side of the Nani Wartabone statue, both tanks are made from France but have different specifications. The tank has no historical value or is not related to the statue of Nani Wartabone, the tank is only displayed to enhance the appearance of the Nani Wartabone struggle (Figure 6 and Figure 7).

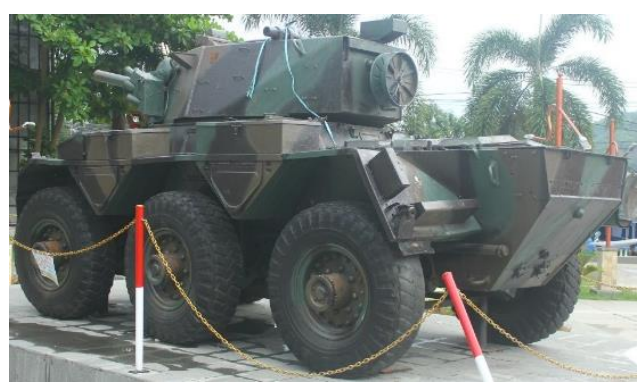

Figure 6. Tank FV601

(Photo source: Author, 2018)

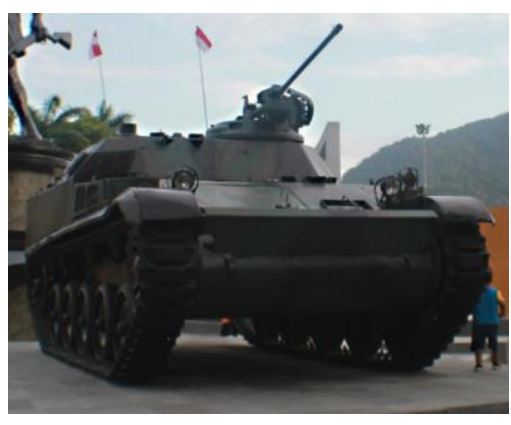

Figure 7. APC AMX-13 Tank (Photo source: Author, 2018)

\subsection{Comparison of Visualization of Hero Statues in Bandung}

There are several warrior statues displayed in military form such as the statue of Nani Wartabone in West Java, precisely in the city of Bandung. Like the statue of Nani Wartabone, these statues also have high historical value so they are enshrined in the form of sculptures. These sculptures include the statue of Husein Sastra Negara, the statue of the Bandung Student and the Bandung Battalion Statue. The following will describe a brief description of the three statues.

\section{Statue of Husein Sastranegara}

Husein Sastranegara was born in Cianjur, West Java on January 20, 1919 and died in Yogyakarta, September 20, 1946 when he was 27 years old. Husein Sastranegara was one of the pioneers of the Air Force together with Agustinus Adisucipto, Halim Perdana Kusuma, Abdulrahman Saleh and Iswahyudi.

Air Officer I Husein Sastranegara was killed along with aircraft engineer Sgt. Maj. Air Rukidi during training with a Cukiu aircraft that crashed in the village of Gowongan Lor, Yogyakarta on September 26, 1946 (Figure 8). 


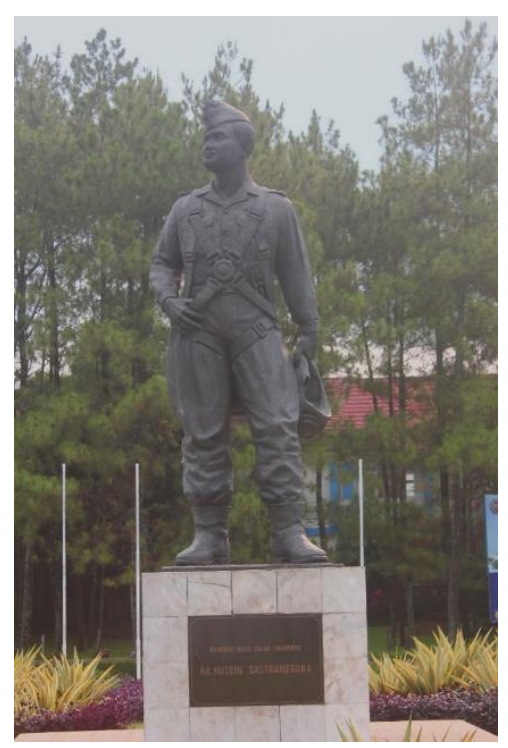

Figure 8. Statue of Husein Sastranegara (source: Author, 2019)

Based on the Decree of Rafter No. 76 In 1952 his name is now enshrined at Husein Sastranegara International Airport and Husein Sastranegara Air Base, Bandung to replace the name Andir Air Base. And there are two statues of Husein Sastranegara, the statue which is located close to the Sompil Basuki VIP Room, Husein Sastranegara International Airport, Bandung and on J1. Padjadjaran (near the airport's main entrance), the Husein Sastranegara Monument was inaugurated by the Air Force (AU) chief of staff Mr. Utomo on Saturday, January 27, 1990.

The location of the Husein Sastranegara Statue is in downtown Bandung or precisely on Jl Padjadjaran Kec. Cicendo, Bandung City, West Java. The place where the statue was made is the place where the statue of Husein Sastranegara was built because it coincided with the door of the Husein Sastranegara Air Base, which was formerly known as the Andir airbase. The location of the Husein Sastrangera statue is also not far from the Husein Sastranegara International airport.

\section{Bandung Student Statue}

In the Viaduk area, Jalan Kebon Jukut, Jalan Pioneer Pioneer, Independence, Jalan Suniaraja, and Jalan Timur Station are two statues of warriors. The statue is named the statue of the army of women. Meanwhile, another one is a statue of a student army. Two statues in the Viaduk area flank the railroad bridge (viaduk). Like the statues of other warriors, the two statues are each in uniform during the revolutionary era.

Not far from the statue flows the Cikapundung River which divides the city of Bandung. Then there is the locomotive monument which is right in front of the Headquarters of PT Kereta Api Indonesia (KAI) Persero. Both statues are the work of Sunaryo, a sculptor from Bandung. Sunaryo is an ITB Fine Arts alumnus. In addition to the two statues, Sunaryo also made the Bandung Lautan Api monument in the Tegalega Square in Bandung.

The two statues were inaugurated by the Mayor of Bandung, Husein Wangsaatmaja, on November 10, 1981. The model for the statue of the female army was Tuti Amir, a Laswi veteran. The Indonesian Women's Warriors Monument (Laswi) is to commemorate the work of Indonesian women in the struggle for Indonesian independence. Laswi was formed on October 12, 1945. They are female students from secondary schools in Bandung. They are trained in military skills such as firing, disassembling weapons and self-defense (igire 9 and Figure 10) 


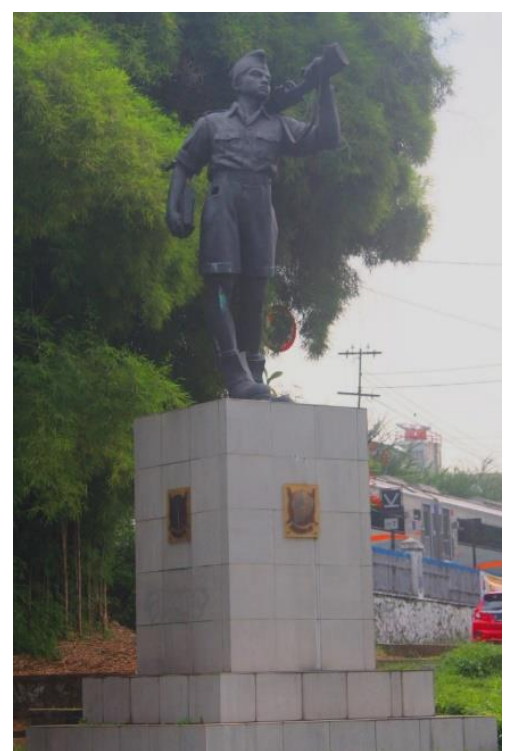

Figure 9. Statue of the Student Army (Source: Author, 2019)

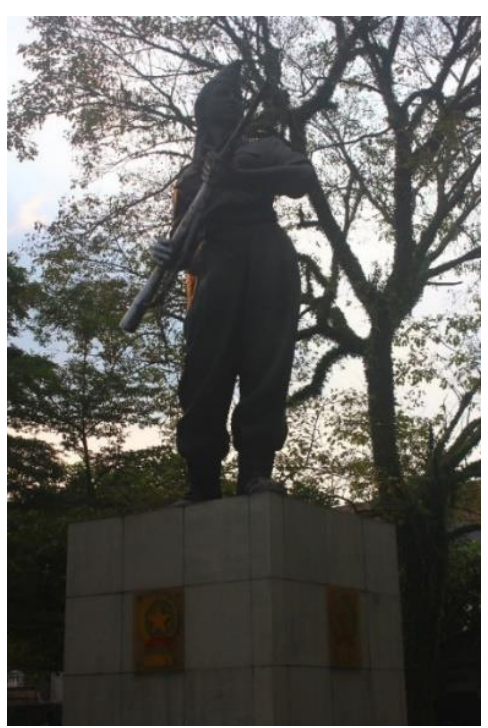

Figure 10. Statue of the Indonesian Women's Warriors (Source: Author, 2019)

\section{Bandung Battalion Statue}

Battalion statue is one of the statues located in Bandung, West Java precisely Jl. Dr. Setiabudi No.229, Isola, Kec. Sukasari, City of Bandung, West Java. This statue was inaugurated in conjunction with the National Monument of the Indonesian Education University (UPI), which was formerly known as the Teaching and Education Institute (IKIP) by the governor of West Java Ahmad Heryawan who was accompanied by the UPI Rector Prof. Dr. H. Sunaryo Kartadinata on May 2, 2015.

Battalion statue is one of the historical evidence in the city of Bandung in the struggle for the independence of the Republic of Indonesia, especially in the area of North Bandung along with other soldiers (Figure 11)

\section{CONCLUSIONS AND SUGGESTIONS}

\subsection{Conclusion}

Gorontalo people built a Statue to remember and commemorate the services of the National Heroes who were in Gorontalo, namely by making a monument in which there is a Statue that has enormous historical value for the Gorontalo area. The statue is a statue of Nani Wartabone who is a hero who is very meritorious in Gorontalo against invaders.

\subsection{Suggestion}

* The clothes on the Nani Wartabone Statue do not refer to the history of the Nani Wartabone war, which probably only uses civil society clothing and the lack of sources or books that are made specifically to discuss the Nani Wartabone Statue, which causes the lack of public knowledge about the Nani Wartabone Statue. 


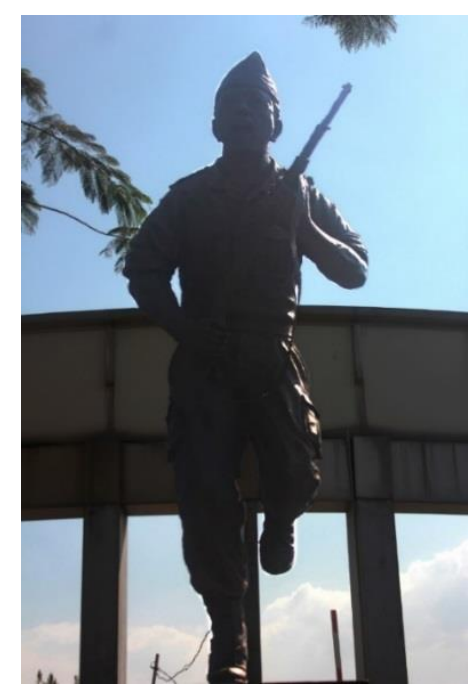

Figure 11. Battalion Statue (Photo Source: Author, 2019

* There are many Gorontalo people who do not know about the statue of Nani Wartabone, especially young people, this is due to the lack of socialization about the history of Gorontalo from the past until now. To overcome this, it is necessary to hold a socialization about the history of Gorontalo to the people of Gorontalo, especially to young people.

* To prevent the loss of history from Gorontalo and the Nani Wartabone Statue, special activities need to be held that discuss the history of Gorontalo and the Nani Wartabone statue through both formal and informal activities. In addition, additional sources are needed to discuss the history of Gorontalo and the statue of Nani Wartabone, both through books, the internet and other sources that support the Gorontalo community to be able to access whenever and wherever they are.

\section{ACKNOWLEDGMENT}

Praise to Allah SWT, because with His grace and grace the author can compile this research entitled "Study of the Statue of the Struggle Nani Wartabone Monument Through the Background and Visualization". On this occasion the author also expressed his highest thanks to Mr. Prof. Widagdo, Dipl, Inn, Arch who have deigned to spend time, energy and thoughts to direct the writer in completing this report.

\section{REFERENCES}

[1] Abd Rahman Hamid dan Muhammad, SH. (2011). Pengantar Ilmu Sejarah. Yokykarta : Ombak.

[2] Jono Irianto, Asmudjo. dkk. (2005). relasi dan ekspansi medium seni rupa. Bandung : Institut Teknologi Bandung.

[3] Kartodirdjo, (1994). Sejarah Lokal Gorontalo: Dinas Pendidikan dan Kebudayaan Provinsi Gorontalo.

[4] Sumartono, (2017). Metodologi Penelitian Kualitatif Seni Rupa dan Desain. Jakarta : Universitas Trisakti. 